\title{
Fotografía y antropología en España (1839-1936): entre el estereotipo y la sistemática
}

\author{
luis Calvo Calvo \\ Departamento de Historia de la Ciencia \\ Institución Milá y Fontanals. CSIC. Barcelona
}

\section{PRESENTACIÓN}

El interés por la relación entre fotografía y antropología ha tenido un notable auge en España en las últimas décadas; a pesar de ello, llama poderosamente la atención que, hasta la fecha, sean escasos los estudios que analicen, con la sistemática requerida, dicha relación. Entre las diversas razones que se podrían apuntar, cabe hacer mención de una, heredada en buena medida de la misma evolución disciplinar general: la importancia del texto como instrumento descriptivo prioritario en la antropología por encima de la imagen, circunstancia que se remonta al período de entreguerras.

En España se han dado aproximaciones parciales al tema ${ }^{1}$, especialmente a partir de la década de los noventa ${ }^{2}$. Este artículo pretende explorar dicho campo, intentando, más que ofrecer una genealogía concreta de los inicios ${ }^{3}$ o de los desarrollos posteriores, crear un marco de reflexión a partir del estudio de las diversas variables y direcciones de trabajo que han estado presentes en el diálogo imagen-cultura desde 1839 hasta 1936, fecha lí-

1 Entre las primeras actuaciones que se han dado, desde la institucionalización de la antropología, hay que mencionar la que llevó a cabo la Filmoteca Nacional de España en Madrid, en mayo de 1977. Al respecto, ver Antología del cine antropológico (Madrid: Filmoteca Nacional, 1977).

2 Entre las publicaciones, hay que destacar la obra de Elisenda ArDÈvol y Luis PÉREZ TOlÓN, Imagen y cultura. Perspectivas del cine etnográfico (Granada: Diputación Provincial de Granada, 1995); entre las reuniones científicas, cabe reseñar el Seminario Internacional de Antropología Visual (Universidad Complutense de Madrid, 49 de marzo de 1996). Al respecto, ver Carme CAZALlA, "Reflexions entorn al Seminari Internacional d'Antropologia Visual", Revista d'Etnologia de Catalunya, 10 (1997), pp. 151-152.

3 Ver Juan NARANJo, "Photography and Anthropology in Spain", History of Photography, 21, n. ${ }^{\circ} 1$ (1997), pp. 73-80. 
mite de este trabajo. Las afirmaciones y las conclusiones que aquí se presentan, tienen un carácter provisional, hallándose sujetas a revisión, sobre todo porque se tiene presente que, como Emmanuel Garrigues ha escrito, indagar en dicha relación supone realizar un verdadero ejercicio de arqueología de los saberes antropológicos": recuérdese que ambas disciplinas, fotografía y antropología, empezaron a desarrollarse casi al unísono y, desde los primeros instantes de la divulgación de la fotografía, ésta ya fue usada como complemento del trabajo antropológico, de manera especial en todo lo relacionado con el estudio físico del hombre.

De esta forma, la imagen adquirió un papel de primer orden en los análisis antropológicos, hasta el punto de que cuando algunas etnias (por ejemplo, los gitanos españoles o los aborígenes de las praderas estadounidenses) fueron fotografiadas, se confirmó que realmente eran "indios", "primitivos" e "incivilizados", lo que ratificó antiguas creencias sobre los modos de vida, diferentes a los estándares.

\section{VARIABLES}

Si se considera que, tal como dijo Julio Caro Baroja, "el ojo, órgano fundamental de percepción en el hombre [...] se carga de notas varias, según el ámbito social en que vive su poseedor y según la cultura que tiene la sociedad en la que ha nacido [...] es un órgano con significado social o colectivo" ${ }^{4}$, hay que tener en cuenta que en la conformación de la fotografía realizada con fines antropológicos $-\mathrm{O}$ aquella que presenta un mayor interés para la disciplina- han incidido diversas variables que, desde mi punto de vista, hacen referencia a cuatro grandes aspectos: los relacionados con el desarrollo de las técnicas fotográficas y, por lo tanto, con la propia evolución de la fotografía; los que tienen que ver con los arquetipos culturales y las consideraciones sobre el mito nacional; el contexto ideológico en el que se desarrolla la relación fotografía/antropología y, finalmente, aquellos que hacen referencia a la propia evolución de la antropología como ciencia. Antes de iniciar el análisis pormenorizado, hay que recordar la estrecha interdependencia existente entre todos ellos; en este sentido, la mayoría de los ejemplos que se presentan pueden perfectamente ser ilustrativos de cualquiera de las variables citadas.

4 Julio CARO BAROJA, Arte Visoria y otras lucubraciones pictóricas (Barcelona: Tusquets, 1990), p. 18. 


\section{La evolución de la técnica y de los estilos fotográficos}

Sin querer afirmar un determinismo absoluto de lo técnico en la fotografía, hay que reconocer que las posibilidades que ofrece la tecnología de magnificar, reducir, aislar o, incluso, idealizar los temas o los sujetos, se convierte, de hecho, en un importante condicionante, facilitando que el fotógrafo pueda ofrecer su propia y singular interpretación de lo registrado. Esta situación se acentuó, al menos en las primeras décadas de la fotografía, por las propias condiciones de los equipos fotográficos, los cuales hacían que, por ejemplo, los modelos se viesen obligados a permanecer en posturas forzadas para que la imagen que se obtuviese fuese correcta, nítida, etc. Al respecto son ilustrativas las palabras de Charles Clifford cuando dijo que:

Los problemas que encuentra un fotógrafo en su trabajo en España no son pocos viajando en un país como España en el que se desconocen las comodidades del transporte [...] por imperativos del considerable tamaño de las fotografías, el equipo debe ser necesariamente grande y puede llegar a pesar hasta 300 kilos... Con toda esta parafernalia debidamente equilibrada y sujeta a lomos de mulas y hasta nuestra animosa persona cargada de similar manera, iniciamos nuestras diarias expediciones a las cuatro de la mañana. Imagínese nuestra desesperación y desasosiego a cada tropiezo de estos orejudos animales, que amenazaban con destruir nuestras frágiles lentes, placas y cubetas 5 .

Como es fácil de imaginar, tales condiciones suponían actitudes, gestos y posiciones alejadas, en buena medida, de la gestualidad natural y cotidiana. Mas, a pesar de ello, hay que reconocer que algunos fotógrafos, como Laurent o el citado Clifford, han dejado un legado de gran importancia por su valor documental.

Estos aspectos se vieron acompañados por lo que se ha dado en llamar la "platonización" ${ }^{6}$ de la realidad - en otras palabras, todos aquellos procesos en los que entran en juego diferentes variables que propician la substitución de la imagen fotográfica por la realidad o viceversa, o sea, idealización-. Como producto de una nueva época, la industrial, la fotografía no fue un instrumento más, sino que rápidamente adquirió nuevos roles, más allá del simple registro. Así, por ejemplo, contribuyó, de ma-

5 Charles Clifford, A Photographic Scramble Through Spain (London: Marion and Co, c. 1862).

6 Ver Lee FonTANella, "150 años de fotografía: contemplación y fotografía", G. F. Kurtz e I. Ortega (coords. y dirs), 150 años de fotografia en la Biblioteca Nacional (Madrid: Ministerio de Cultura/Eds. El Viso, 1989), p. 27. 
nera decisiva, a difundir ciertas imágenes tópicas de unos u otros grupos humanos a partir de un mecanismo - propiciado por la misma técnica fotográfica- de descontextualización del hecho cultural. En este sentido, uno de los ejemplos más claros es el relacionado con el orientalismo ${ }^{7}$, que puso al descubierto las relaciones de poder, el tiempo de la colonización y la forma en que los nativos fueron aprehendidos por el imaginario occidental ${ }^{8}$. El orientalismo se manifestó a través de múltiples configuraciones, entre ellas las fantasías que emergieron en la literatura y en la pintura europeas del siglo pasado. Los sueños occidentales sobre Oriente fueron revelados en las representaciones de míticos desiertos, agrestes paisajes, mujeres semidesnudas, etc. Las fotografías del período que analizamos presentan unas formas de vida que reafirman la imagen de unos mundos marginales y secretos, de unos universos subterráneos poblados de seres raros y extraños ${ }^{9}$. De esta forma, la fotografía no sólo certificó la existencia de un Oriente que antes nunca había sido captado, sino que ayudó poderosamente a crearlo ${ }^{10}$.

A todo ello hay que añadir la propia evolución de los estilos o modas fotográficas, algunas de las cuales contribuyeron, de manera poderosa, a reafirmar la citada "platonización"; en este sentido, fue significativo el movimiento del pictorialismo, caracterizado por las "composiciones alegóricas, de barrocas escenificaciones y todavía más de pretenciosos significados" ${ }^{11}$.

\section{Los estereotipos nacionales y la recreación de la realidad}

La utilización de cualquier nueva técnica, en nuestro caso la fotografía, nunca se ha dado aislada del contexto que la vio nacer. De esta manera, lo que podríamos definir como la "tipificación tópica" de la realidad nacional jugó un papel destacado en aquello que se quiso captar. En este senti-

7 Ver Mounira KHEMIR, L'Orientalisme. L'Orient des photographes au XIX siècle (Paris: Centre National de la Photographie, 1994).

8 C. M. GEARY, "Impressions of the Africa Past: Interpreting Ethnographic Photographs from Cameroon", Visual Anthropology, 3, n. ${ }^{\circ} 2-3$ (1990), p. 291.

9 D. PROCHASKA, "L'Algerie imaginaire. Jalons pour une histoire de l'iconographie coloniale", Gradbiva, 7 (1989), pp. 32-33.

10 Ver C. M. GEARY, "Impressions of the Africa Past: Interpreting Ethnographic Photographs from Cameroon", p. 291.

11 Joan FONTCUBERTA, "Apéndice: Notas sobre la fotografía española", Beaumont Newhall, Historia de la fotografia. Desde sus origenes hasta nuestros días (Barcelona: Gustavo Gili, 1982), p. 306. 
do, los ejemplos son muchos. Piénsese por un momento en las imágenes, literarias y visuales, que los viajeros románticos propagaron de España, imágenes que, en gran medida, han marcado, hasta tiempos relativamente recientes, la visión y la consideración sobre España. Recuérdese, a modo de ejemplo, la descripción de Merimée en sus Lettres adressées d'Espagne au Directeur de la Révue de Paris (1830): España se caracterizaba por sus corridas de toros, las ejecuciones y los bandoleros. Por su parte, Alfred Fouillée decía en su Esquisse psychologique des peuples européens que uno de los rasgos más acusados de los españoles era su carácter semiafricano, es decir, violento y fanático; apreciaciones que coincidían con las realizadas por el futuro primer ministro británico Benjamín Disraeli cuando, en el verano de 1830 , describía el estado semisalvaje de los españoles ${ }^{12}$. El pintoresquismo y un cierto exotismo ${ }^{13}$ fueron elementos presentes en muchas descripciones, como las de los viajeros ingleses Borrow o Ford. Estos rasgos se acentuaban cuando el objetivo final del viaje era llegar a Andalucía, quintaesencia de los tópicos, así como lugar donde habitaba una de las etnias más interesantes para fijar en imágenes: los gitanos. De esta forma, algunos fotógrafos, como el inglés Napper, destacaron por los trabajos que realizaron sobre gitanos andaluces.

Esta serie de consideraciones cristalizaron de tal manera a lo largo del siglo XIX que diversas compañías fotográficas europeas organizaron verdaderas expediciones para captar la realidad española; publicaciones como la de Georges Washington Wilson, Catalogue of Landscape, Architectural and Figure Photographs of Gibraltar South of Spain and Morocco (Escocia: Wilson d'Aberdeen, 1890) o las de la familia Levy de París son un buen ejemplo, trabajos todos ellos que recurren, en gran medida, a los tópicos (herencia árabe, paisajes pintorescos, tipos toscos, mujeres exhuberantes...). Con todo, algunas de estas publicaciones ofrecen buenos testimonios de diferentes aspectos de la realidad española del momento. Este interés continuó a lo largo del siglo $\mathrm{xx}$, tal como lo demuestran trabajos como, por ejemplo, los de Kurt Hielscher (La España Incógnita. Arquitectura, Paisajes. Vidas Populares. Madrid: Espasa Calpe, C. 1920-s) o Eugene Smith ("Spanish Village,. Life, $1953{ }^{14}$ ).

12 Ver David MiTchell, Viajeros por España (Madrid: Mondadori, 1988), p. 61.

13 Hay que tener en cuenta que estas consideraciones no se redujeron solamente al ámbito cultural o literario, sino que en los medios antropológicos europeos también existieron dichas opiniones. Así, España, al igual que otros países mediterráneos, fue denominada por la etnología alemana de principios del siglo xx bajo el término de nunbenkannte", es decir, "desconocido", aquello que estaba por descubrir y que se hallaba en un estado casi virginal.

${ }^{14} \mathrm{Al}$ respecto, ver el artículo de $\mathrm{S}$. Brandes y $\mathrm{J}$. de Miguel que se publica en este mismo dossier. 


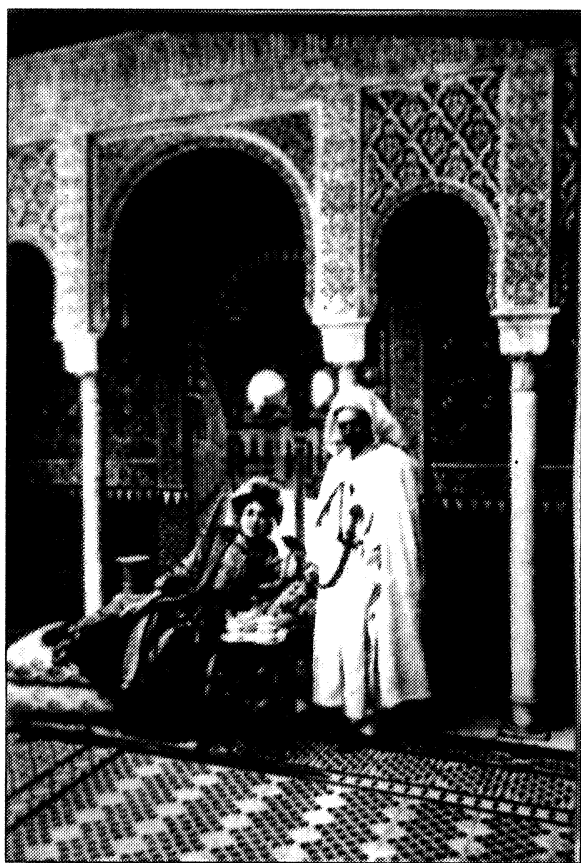

FIG. 1.

Pero hay que tener en cuenta que los estereotipos no solamente fueron una de las claves de los fotógrafos extranjeros en España; buen número de fotógrafos españoles también tuvieron este aspecto como eje de su actuación. A pesar de que las motivaciones fueron diferentes, con la popularización de la fotografía, a partir de 1860 aproximadamente, en muchos estudios fotográficos, especialmente los concebidos para retratar personas, se montaron auténticas escenografías y espacios ilusorios, donde ciertas recreaciones, por ejemplo el mundo de los toros, fueron frecuentes: así, fue aceptado fotografiarse con cabezas de toros, etc. Estas recreaciones tuvieron tal éxito que incluso se llegaron a ofrecer a los clientes los llamados "catálogos de ambientes", donde se mostraban ambientaciones "exóticas" (por ejemplo, árabes).

\section{Las corrientes de pensamiento}

El siglo XIX, como es bien conocido, está marcado, científica y culturalmente, por algunas corrientes de pensamiento que tuvieron una repercusión destacada; además del movimiento romántico, no se puede olvidar la incidencia del positivismo y del nacionalismo. Así, en lo fotográfico, fiel reflejo del racionalismo fue el trabajo de autores como Clifford, que documentó, de manera precisa y casi empírica con un sentido muy cercano a lo experimental, gran número de actividades de la vida española, como la construcción del Canal de Isabel II ${ }^{15}$. En lo que respecta al tema del nacionalismo, no se puede olvidar su incidencia, especialmente en la Es-

15 Asimismo, y a pesar de que su obra ha sido denominada como "esteticista", no hay que olvidar los trabajos de José Spreafico y sus imágenes sobre la construcción del ferrocarril Málaga-Córdoba, donde documentó múltiples aspectos de esta obra de ingeniería civil. 
paña finisecular. Uno de los casos más significativos se encuentra en Cataluña con el movimiento de la Renaixença, el cual, además de la literatura, estimuló, diría que de manera decidida, el uso de la imagen, en sus diversos formatos (grabado, fotografía...) con vistas a fomentar el sentimiento por lo propio. Así y a modo de ejemplo, la Associació Catalana d'Excursions Científiques editó en 1879 el primer Album Pintoresch ${ }^{16}$, donde Manuel Milá y Fontanals hizo un claro manifiesto en favor de lo visual; esta obra tuvo continuidad en otras muchas iniciativas que buscaron documentar la geografía y la cultura catalanas; entre ellas, cabe citar la iniciativa del Inventari Gráfic de Catalunya, auspiciada por el Centre Excursionista de Catalunya en 1909.

Junto a las corrientes de pensamiento de carácter general y de amplia resonancia en Europa, también hay que referirse a acontecimientos $o$ movimientos más específicos que se dieron en España; el caso más destacado fue el de la crisis de 1898 y sus consecuencias en la sociedad y en la cultura españolas. En este sentido, el denominado regeneracionismo también tuvo sus repercusiones en el ámbito fotográfico y algunos autores contribuyeron con su trabajo a plasmar en fotografías lo que algunos literatos describían en sus creaciones: captar el alma hispana, el carácter adusto, etc. El ejemplo más representativo es el de José Ortiz Echagüe (1886-1980), cuya obra se extiende hasta la segunda mitad de nuestro siglo. Su primera gran publicación, Spanische Köpfe (Berlín: Ed. Wasmuth), data de 1929. En ella se encuentra una de las más claras muestras de la interdependencia entre una situación socio-cultural determinada y una realización fotográfica; así, hay que tener en cuenta que este autor "seleccionó ciertos personajes que concordaban con unos estereotipos previos, bus-

16 Esta obra quería presentar los aspectos más destacados de la geografía y del arte catalán; el prólogo, realizado por Manuel Milá y Fontanals, mostró, en primer lugar, la visión romántica de la Renaixença y, por otra parte, la importancia de la representación gráfica: "Molt hi há de fet, més resta que fer. Encontradas enteras son si fá no fá desconegudes, altras no s'han registrat prou y entre lo conegut hi há molt de no publicat [...] Encara que no's tractés sino de la publicació de novas estampas, fora ja fer un bon servey, no sols perque ab ellas se perpetúa la memoria dels objectes que no's poden salvar de la destrucció (los quals en realitat son pochs si hi há bona voluntat), sino perque ensenyen als mateixos ignorants qu'han d'estimar las cosas que valen la pena de ser representades, serveixen ademés pel gust y l'instrucció dels que no poden veure 'ls originals y pel recort dels que 'la han vist, de naturalesa ó costums més subjectivas que objectivas, ó com s'ha dit molt bé, més musicals que pintorescas, só es, més aptas pera recordarne particularitas [...] «. Manuel Milà I Fontanals, "Introducció al Album Pintoresch Monumental de Catalunyan, Marcelino Menéndez Pelayo (ed.), Obras completas del Dr. D. Manuel Milá y Fontanals (Barcelona: Librería de Álvaro Verdaguer, 1893), vol. V, pp. 449-450. Se ha conservado la ortografía original. 
cando la idea de riqueza étnica, personalidad colectiva, enraizamiento histórico y, en definitiva, dignidad nacional [...] se limitó a ambientes rústicos - el tiempo detenido- evitando la contemporaneidad" ${ }^{17}$. Las palabras de Azorín prologando la obra de Ortiz Echagüe, España. Pueblos y paisajes (Madrid: Publicaciones Ortiz Echagüe, 1943), reflejan el espíritu y la intencionalidad del fotógrafo:

Hay un campo en que un labriego, la mano en la mancera, va abriendo un surco con arado romano; y hay otro labriego que al cabo de diez siglos abre el mismo surco con el mismo arado; hay en la calle silenciosa de pueblo, en porche o patio de casa, un tejedor que con el pie en la premidera anda el telar; y hoy, al cabo de los siglos, otro tejedor hace que del mismo modo vaya la lanzadera de un lado a otro ${ }^{18}$.

La interdependencia entre fotografía y circunstancias socio-culturales y políticas, en relación con nuestro objeto de estudio, no se circunscribió al período anterior a 1936; de hecho, se puede decir que hasta bien entrados los años sesenta, las condiciones socio-políticas hicieron que en España se diesen ejemplos de cómo la fotografía se convirtió en un fiel reflejo de la ideología del momento. Como ya se sabe, durante este período se hizo hincapié en el mundo rural como paradigma de la sociedad: el campesinado se presentó como el depositario de las mejores actitudes y aptitudes del carácter nacional; así, el agro ibérico se presentó como la mejor expresión del racialismo orgánico y natural español, convirtiéndose en la fuente prístina donde lo más primigenio y lo más esencial todavía se conservaba. El acento sobre los valores rurales se inscribió en un modelo orgánico de sociedad que encubrió las divergencias sociales efectivas, propiciando una retórica basada en una cierta idealización ahistórica y en una enfatización de algunos rasgos o circunstancias, generándose así una reproducción mixtificada de la realidad, de hecho, una segunda época para el pictorialismo: lo que ha sido denominado como tardopictorialismo. De esta forma, estereotipos y tópicos contribuyeron, de manera poderosa, a que la fotografía reafirmase las imágenes mecanicistas de la realidad cultural española, imágenes que las nuevas generaciones de fotógrafos (F. Català Roca, X. Miserachs, etc. ${ }^{19}$ ) ayudaron a modificar notablemente.

17 Joan Fontcuberta, "Apéndice. Notas sobre la fotografía española", p. 310.

18 Para un análisis exhaustivo de las dimensiones del trabajo de Ortiz Echagüe y su contribución al conocimiento etnográfico hispánico, ver Ortiz Echagüe (Barcelona: MNAC, 1998).

$19 \mathrm{Al}$ respecto, sobre estos dos autores se ha dicho que "la realidad más urgente y obvia era la fuente de inspiración de las fotografías de Català y Miserachs, que destilan algo de documentalismo social y mucho de humanismo", Marta GILI, "Llevar puesto el mundo", El País (14 de septiembre de 1998). Suplemento "Cataluña", p. 6. 


\section{El desarrollo de la antropología}

Con vistas a analizar, en toda su amplitud, la importancia de esta variable, permítaseme repasar brevemente algunos de los rasgos más sobresalientes del desarrollo de la antropología en España hasta su institucionalización a partir de la década de 1970.

Como ya he escrito en otro lugar ${ }^{20}$, en la historia de la antropología española, hasta el momento en que la disciplina inició su auténtico proceso de institucionalización, se dio un determinado modo de trabajar y de entender la antropología; éste se caracterizó porque la idea de "antropología" se alimentaba más de ciertas concepciones filosóficas, morales o jurídicas que de la propia tradición antropológica (pongamos por caso de antropólogos como Tylor, Morgan, Boas, etc.). Como dijo Hermann Bausinger ${ }^{21}$, este modo de hacer venía definido a partir de la investigación de determinados elementos de un grupo o de una comunidad que eran susceptibles de ser considerados como la expresión de una "mentalidad de grupo", relativamente constante en el tiempo y en el espacio, con una fuerte orientación identitaria, producto de una serie de bienes culturales - muebles e inmuebles - que definían dicho grupo de manera más o menos permanente. El estudio de diversas parcialidades (por ejemplo, el arte, la canción, el mobiliario, la casa...), observadas como partes de un todo homogéneo, debería proporcionar imágenes fidedignas de la realidad del colectivo estudiado. Así, conceptos como "comunidad", "tradición", "costumbre" o "continuidad" se aplicaban a todo el espectro social. Estos conceptos se presentaban, por tanto, como los auténticos articuladores de la actuación antropológica. Esta concepción tenía como eje central el punto de vista histórico, lo que hacía que la idea de cultura se configurase a partir de conceptos preexistentes. En base a estos parámetros, el objetivo era reunir el mayor número posible de documentación: el sentimiento de urgencia y de salvaguarda estaba a la orden del día, y de hecho, definía, por sí mismo, la tarea a realizar. Estos trabajos tuvieron como resultado la compilación de gran número de documentos de innegable valor, resultado de la homogeneidad de criterios, aunque la mayoría de las iniciativas tuvieron como punto débil, visto desde nuestros días, el

20 Ver Luis Calvo, Historia de la antropología en Cataluña (Madrid: CSIC, 1997), capítulo final de conclusiones.

21 Hermann Bausinger, "Nouvelles taches, nouvelles méthodes", Isac Chiva et Utz Jeggle (eds.), Ethnologies en miroir (Paris: Éditions de la Maison des Sciences de l'Homme, 1987), pp. 315-331. 
hecho de que solían hacer una etnología o un folklore sobre la comunidad, sin entrar en el análisis de los mecanismos que regían la vida colectiva. De esta forma, esta concepción era altamente atomizadora y, en gran medida, esencialista; siendo ideas como la degeneración de las formas de vida y de la cultura, o las supervivencias de antiguos rituales mágicos, las que definían buena parte de la labor a realizar.

¿Qué plantea este modo de evaluar y estudiar la realidad? Como se ve, un fuerte condicionamiento para la observación y la descripción, ya sea escrita o visual, sobre todo si se considera uno de los aspectos que he mencionado: la degeneración de las formas de vida ${ }^{22}$. Esta idea tenía como soporte fundamental la teoría evolucionista que, en sus argumentaciones decimonónicas, presentaba, si nos referimos a las sociedades occidentales, ciertos sectores (campesinos, obreros, pescadores, vendedores ambulantes, etc.) como la viva representación del atraso sociocultural -incluso físico- que todavía se mantenía en las sociedades desarrolladas.

Este planteamiento, que privilegiaba la desigualdad social y cultural, propició, entre otras cosas, que los grupos sociales más desfavorecidos fuesen incluidos en el término "cultura popular", siendo observados con un fuerte acento exotista, alejados de la civilización, tanto en lo que se refiere a sus comportamientos, hábitats ${ }^{23} \mathrm{u}$ otros aspectos. Así, de la misma manera que los folkloristas estuvieron influidos por esta serie de parámetros e

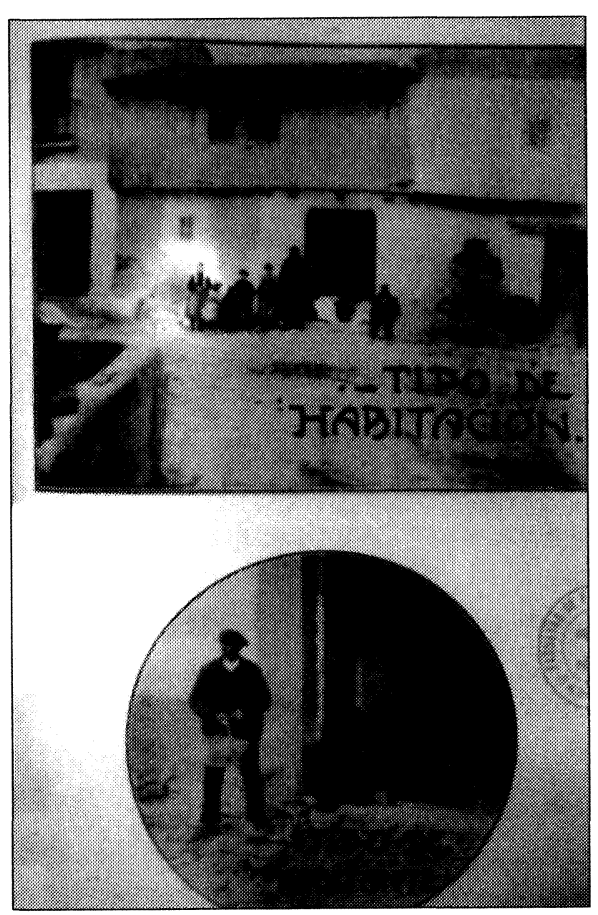

FIG. 2.-Pedro Chico y Rello, "Zamarramala", Revista de Geografía Colonial y Mercantil, 12, n. ${ }^{\circ} 9,1915$.

22 Hay que tener en cuenta que, en buena medida, dicha idea fue aplicada a toda la realidad; así, Gautier en su Viaje a España (1840) escribió: “Es un doloroso espectáculo ver cómo desaparecen del mundo las formas, los tonos y los colores y cómo la uniformidad más desesperante invade el universo, bajo el pretexto de no sé qué Progreson.

23 En este sentido, recuérdese la fascinación que las cuevas del Sacro Monte de Granada ejercieron sobre muchos viajeros románticos. 
ideas en el momento de hacer su trabajo de compilación de las formas de vida, aquellos que se dedicaron a fotografiar la "cultura popular" también estuvieron marcados por los mismos elementos.

Hay que tener en cuenta que ala invención de la fotografía coincidió con una revolución industrial que modificó en profundidad las adscripciones locales, provocó el éxodo rural, acentuó la urbanización y suscitó entre sus actores un sentimiento de su individualidad propia. ${ }^{24}$, pero, al unísono, reforzó los estereotipos sobre el mundo rural y/o popular. De esta forma, se puede entender mejor el porqué de la dedicación de muchos autores registrando la imagen facial de campesinos o pescadores. Parece como si se quisiese encontrar, en algunos casos, el "tipo ideal"; en otros, la presentación de la debilidad mental de los personajes o la profunda ingenuidad de los fotografiados. En este sentido, la producción de

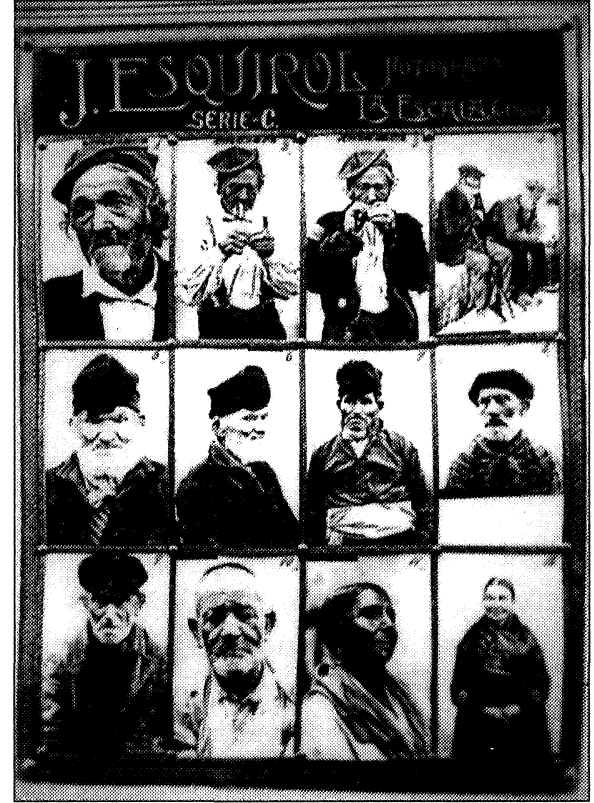

FIG. 3. colecciones o de imágenes individuales de "tipos", se convirtió, al igual que en el resto de Europa, en un auténtico documento científico, que reflejaba, de forma absolutamente veraz, la realidad de la población: ello, inscrito en los nuevos circuitos de consumo cultural de masas que surgieron con la revolución industrial, ayudó a tipificar las realidades culturales. De hecho, se puede decir, como ha señalado acertadamente Elizabeth Edwards, que el fragmento fue elevado a elemento significativo y expresivo de la cultura y las formas de vida.

Como se puede presuponer, estos "documentos" no reflejaban verdaderamente la realidad cultural, ya que se dieron grandes desequilibrios, por ejemplo, entre la documentación sobre el mundo rural y de la pesca, y la de los sectores obreros de las colonias industriales, las fábricas o los trabajos urbanos, etc. A pesar de que el ejemplo está fuera de los límites temporales que me he marcado en este artículo, una buena muestra de la importancia de esta variable se puede apreciar en las imágenes que publicó durante sus pri-

24 David LE BrEton, Des visages (Paris: Métailié, 1992), p. 41. 
meras décadas la Revista de Dialectología y Tradiciones Populares: una somera revisión permite observar cómo el fragmento fue considerado como categoría y muestra significativa de lo que se consideraba como tradición popular; así, en su pórtico programático se puede leer que: "El folklore, arrinconado en los bajos fondos, se enaltece en una gloriosa difusión al dignificarse con ropajes del arte y ser admitido en un ambiente antes desdeñoso para las manifestaciones vulgares” ${ }^{25}$, o cuando se señalaba: «[...] la mayor aptitud del medio femenino para conservar y transmitir folklore. Las mujeres se fijan mucho en los detalles nimios, se los cuentan unas a otras y saben explicarse mejor que los hombres [...] [se] aconseja interrogar en primer término a los ancianos que son los buzones de alcance del pasado" 26 .

Sin quitar mérito al trabajo de documentación que supuso la labor mencionada, hay que tener en cuenta que las imágenes que se realizaron bajo estas premisas, es decir, para reflejar la profundidad y la perennidad del alma, la esencia de la cultura tradicional, etc., han llegado a ser con el tiempo verdaderos argumentos en contra de las mismas consideraciones, raciales y etnocéntricas, que las produjeron: al inmortalizar a aquellos hombres y mujeres "iletrados", sus imágenes, sencillas, simples, muchas veces caracterizadas por su fuerte acento pintoresco o incluso caricaturesco, se han convertido en una victoria gracias al avance del pensamiento social y antropológico ${ }^{27}$.

\section{Fotografía Y ANTROPOLOGÍA EN ESPAÑA (1839-1936): UNA TENTATIVA DE SISTEMATIZACIÓN}

En base a los datos y a las reflexiones que hasta este momento he aportado, se puede decir que, en términos generales, en la fotografía de carácter antropológico realizada en España hasta al menos 1936, se pueden identificar dos grandes tendencias: que, empleando una figura literaria, se podrían denominar como fotografía "exo" o "endo" "exótica". Dichas denominaciones responden, en primer lugar, al ámbito territorial en que se desarrollaron; en segundo término, al hecho de que, en el caso de la palabra "exótica", la fotografía de signo antropológico, realizada entre las

25 Vicente García DE DiEgo, "Tradición popular o folklore", RDTP, I (1944-1945), p. 21.

26 Enrique CASAS GASPAR, "Lecciones de dos maestros: Van Gennep y Corso", RDTP, III (1947), p. 263 y p. 265, respectivamente. La cursiva es mía.

27 M. BANTA \& C. Hinsley, From Site to sight. Anthropology, Photography and the Power of Imagery (Cambridge: Peabody Museum, 1986), p. 58. 
fechas señaladas, tuvo como objeto principal retratar aquello que estaba, en cierta medida, más alejado de las formas de vida estandarizadas y que reflejaba aspectos como el atraso del mundo rural y de sus personajes, el pintoresquismo y el tipismo, imágenes que, en definitiva, expresasen el carácter "recóndito", "pintoresco" y/o "entrañable" (!) de un territorio y de sus habitantes. La realización de fotografías en base a estos parámetros difundió una imagen de la alteridad, propia y foránea, que, si bien delineaba la diversidad cultural, vino a reforzar los tópicos y, en muchos casos, los valores etnocéntricos.

Teniendo en cuenta estas precisiones, se pueden identificar diversas corrientes de trabajo en cada una de estas direcciones, corrientes que, aquí y ahora, quieren solamente ser indicativas de lo mucho que queda por investigar con respecto a nuestro patrimonio histórico fotográfico de carácter antropológico, plataforma fundamental para realizaciones posteriores. Una última consideración antes de entrar en su descripción: a pesar de que más arriba he señalado que el desarrollo de la fotografía y de la antropología fueron parejos, dándose, en muchos casos, una auténtica retroalimentación, hay que tener presente que lo que podría denominarse como "fotografía antropológica", en el más amplio sentido de la palabra, no se da en España hasta finales del siglo XIX y, sobre todo, hasta las primeras décadas de la nueva centuria, cuando, gracias a la actuación del Archivo de Etnografía y Folklore de Cataluña, la fotografía pasó a ser elemento imprescindible del trabajo de los folkloristas y de los etnógrafos, como más abajo se indica. Por lo tanto, la división formal, así como las continuadas referencias a autores, quiere ser más una tentativa por indagar lo antropológico en lo fotográfico; por ello, la provisionalidad preside las siguientes notas, tanto en lo que se refiere a la división establecida como al estudio y/o cita de fotógrafos o corrientes fotográficas.

\section{A. La fotografía exo-exótica}

1. La fotografía colonial.-Ésta fue la realizada en las colonias y excolonias españolas americanas, de Filipinas y africanas ${ }^{28}$. En términos ge-

28 Así, por lo que respecta al Norte de África, la Alta Comisaría de España en Marruecos estimuló la confección de un "Archivo Gráfico". En las indicaciones para su constitución se puede leer que: "Se recibirá con especialísimo interés las fotografías, grabados, dibujos, láminas, acuarelas y cuantos modos gráficos de reproducción representen tipos, vistas de lugares y edificios típicos, de fiestas, usos y costumbres. Es preciso fijar exactamente el sitio y fecha, así como una sucinta descripción de lo representado. En los retratos de los naturales del país, señálese su origen familiar, comar- 
nerales, se puede decir que la fotografía se convirtió en un elemento más para justificar la naturaleza biológica de la cultura y, en la mayoría de los casos, del subdesarrollo de los pueblos colonizados y, por lo tanto, de la necesidad de tutelarlos, así como de guiarlos en su camino hacia el progreso. Ejemplos destacados son los trabajos de Castro durante la expedición al Pacífico (1863-1866) ${ }^{29}$, las imágenes tomadas por militares españoles u otras personas en las colonias españolas africanas (Marruecos, Guinea, Sahara) ${ }^{30}$ o las de los exploradores o comerciantes españoles o de otro

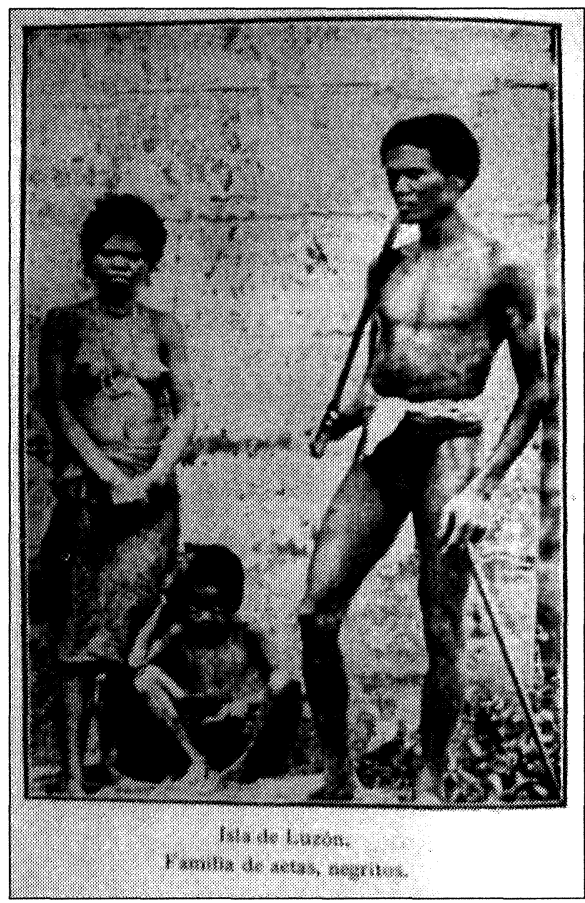

FIG. 4. origen que publicaban sus reportajes, acompañados de un número significativo de fotografías, en publicaciones diversas. Un buen ejemplo lo ofrece el estudio de Enrique D'Almonte, "Formación de las subrazas indonesia y malaya" (Boletin de la Real Sociedad Geográfica, [Madrid, 1917], LIX, pp. 1-110).

\section{La fotografía misional.-De} este tipo de fotografías fueron las realizadas por los religiosos españoles destacados en otros continentes en misiones de evangelización. Muchos religiosos documentaron, de manera notable, las formas de vida de otras culturas, gracias a lo cual se conserva la memoria, sin entrar en otras consideraciones, de algunos pueblos. Recuérdese el caso de los Yámana de la Tierra del

cal o forastero". Alta Comisaría de España para Marruecos. Investigación científica de Marruecos (Larache, 1940), p. 37. En el caso de Guinea, hay que destacar los trabajos que diversos militares y colonos realizaron y, especialmente, los auspiciados por el Instituto de Estudios Africanos desde 1940 hasta la década de los sesenta. Al respecto ver, Luis Calvo Calvo, "África y la antropología española", RDTP, LII (1997), pp. 169-185.

29 Ver M. A. Puig SAMPER, "El fotógrafo de la Comisión científica del Pacífico 18621866", M. A. Calatayud y M. A. Puig Samper (ed.), Pacífico Inédito 1862-1866 (Madrid: Lunwerg, 1992), pp. 21-27.

30 Ver Pilar Romero DE TEJADA, "Los españoles del siglo XIX en África y las colecciones del Museo Nacional de Etnologían, Actas del Primer congreso Español de Antropología (Barcelona: Universidad de Barcelona, 1980), vol. I, pp. 39-61. 


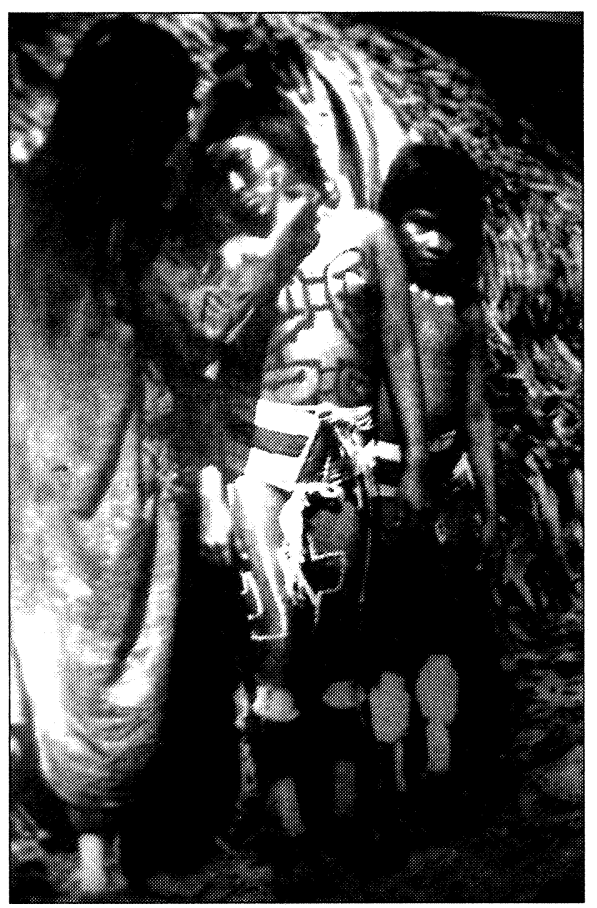

FIG. 5.-Tribu Bora a Cumimarima: madre pintando a su hija para un baile ritual. Fondo gráfico de la Província de Framenors Caputxins de Catalunya
Fuego, hoy ya desaparecidos ${ }^{31}$. El trabajo fotográfico de estos religiosos, stricto sensu, no fue una labor con una clara finalidad etnográfica pero sí que aportó datos importantes sobre las culturas, aunque un análisis detallado permite observar aspectos que muestran la impronta del ideal religioso que les movía, detalles que comportaban una alteración de las actitudes, posturas u otros aspectos con vistas a favorecer siempre la centralidad del mensaje religioso, tal como se puede observar en buen número de publicaciones, especialmente las de carácter periódico (por ejemplo, El Correo Sino-Annamita, editado en Manila por las Misiones del Sagrado Orden de Predicadores). Entre los muchos ejemplos que se podrían citar sobre el valor etnográfico de las imágenes realizadas por los misioneros, me remito a la labor de la Provincia Capuchina de Cataluña en la Amazonía colombiana, en el denominado por muchos "Infierno Verde", donde diversos religiosos de dicha Orden realizaron una meritoria labor, muy cercana a la etnografía ${ }^{32}$.

\section{B. La fotografía endo-exótica}

1. La fotografía "pintoresca" o costumbrista.-Antes de presentar propiamente este tipo de fotografía, debo aclarar el sentido de la acepción "pintoresca", que debe entenderse, fundamentalmente, como "aquel con-

31 Ver, por ejemplo, Martin Bausinger, Fueguinos (Sevilla: Escuela de Estudios Hispanoamericanos, 1951).

32 Ver Luis Calvo y F. Valentí Serra De MANRESA, Catalunya a l'Amazònia. Obra etnolingüística dels caputxins (Barcelona: Província de Framenors Caputxins de Catalunya, 1991). 


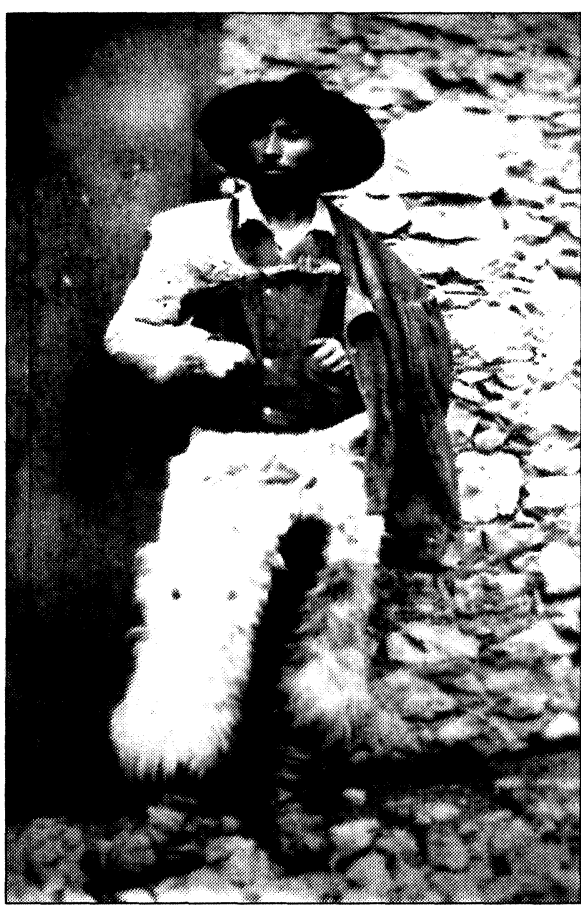

FIG. 6.

junto de prácticas que engloban una gran variedad de objetos visuales y de estrategias ideológicas" ${ }^{33}$. En este sentido, el género "pintoresco" en fotografía representa una visión simplificada y codificada de la realidad ${ }^{34}$, en la que los individuos son fotografiados fuera de su contexto cultural y de su medio físico habitual, desgajándolos así de su mundo real; este tipo de fotografía creó la ilusión de lo real ${ }^{35}$ a partir de la utilización de la abstracción como estrategia.

El auge de la fotografía pintoresca de carácter etnográfico tuvo como uno de sus ejes la explotación del tópico y del estereotipo sobre nuestro país ("Leyenda $\mathrm{Ne}$ gra", país atrasado, bárbaras costumbres, reminiscencias orientales y exóticas, etc.) ${ }^{36}$, lo que, entre otras cosas, hizo que algunas áreas - por ejemplo, Andalucía- se convirtiesen en punto de destino de gran número de fotógrafos por su "exotismo": monumentos árabes, gitanos, toros, etc. Así, fotógrafos como Claudius G. Wheelhouse, E. K. Tenyson, Charles Clifford, Louis de Clerq o R. P. Napper recalaron en Sevilla con el objetivo de fotografiar todos estos aspectos; es lo que se conoció más tarde como "Morish Style». Junto a éste, el paisaje y los tipos fueron los preferidos por los fotógrafos extranjeros $-\mathrm{y}$ varios españoles, caso de Alguacil o Garzón-, aunque los trabajos de algunos

33 D. Prochaska, "L'Algerie imaginaire. Jalons pour une histoire de l'iconographie coloniale", p. 36.

34 Ibidem.

35 Ibid., p. 37.

36 Un ejemplo de los tópicos y estereotipos nos lo ofrece el comentario del escritor holandés C. A. FISCHER, Voyage en Espagne aux années 1797-1798 (Paris, 1801): «Hace treinta años un viaje a España era considerado como un viaje al fin del mundo. Cómo era posible [...] desear ir a visitar un país que, desacreditado como estaba por culpa de la Inquisición y la barbarie de las costumbres, no ofrecía al extranjero ninguna compensación por los peligros y contrariedades que debía afrontarn. 
como Clifford, Laurent ${ }^{37}$ o Napper, a partir de lo que Joan Fontcuberta ha denominado "estética documental, realizaron imágenes muy valiosas para el conocimiento etnográfico de España, reflejando la entidad humana de los personajes fotografiados. En algunos casos, las imágenes fueron tomadas sin ninguna artificiosidad, con gran vigor e intencionalidad, aunque algunas adolecían de una gran rigidez debido a los condicionantes técnicos ya señalados.

Hay que tener en cuenta que no solamente los fotógrafos foráneos realizaron este tipo de imágenes sino que también los españoles recurrieron al pintoresquismo con vistas a conseguir una mayor difusión de sus trabajos; de esta forma, fotografiaron, amén de los consabidos monumentos árabes, escenas de género, oficios, bandoleros, toreros, gitanos y bailadoras. Este tipo de imágenes se vio reforzado cuando se puso de moda, hacia finales del siglo XIX y primeras décadas del siglo XX, fotografiar composiciones de escenas literarias o poéticas, así como máximas famosas; recuérdense, por ejemplo, los trabajos de Antonio Cánovas, conocido como "Kaulak", (Quién supiera escribir"), o de otros autores como el valenciano José Grollo ("Señora y pedigüeña"): su producción tuvo un fuerte sentido pictorialista debido al marcado acento alegórico ${ }^{38}$.

2. La fotografía antropobiológica.-Ésta abarca tanto la realizada por los escasos antropólogos físicos que España tuvo en el período señalado como la que se realizó con fines médicos ${ }^{39}$. No voy a entrar en mayores pormenores, pero sí tengo que hacer mención, al menos en lo relacionado con los estudios de los antropólogos físicos, a la importancia de las teorías relacionadas con el origen y la evolución de los pueblos. Así, la teoría de la etnogénesis de las poblaciones fue uno de los vectores más

37 Ver J. Laurent, I (Madrid: Ministerio de Cultura, 1983).

38 Ver nota 11.

39 A pesar de que no existe gran número de estudios sobre la relación entre fotografía, medicina y antropología, es interesante mencionar la importancia que tuvo la fotografía durante una época - antes de la invención de los rayos X-, con la particularidad de que ésta no fue tan sólo utilizada en los estudios propiamente médicos sino que también se usó como elemento de moralización, tal como lo refleja el siguiente comentario [en relación con la sífilis]: "Entran con alguna frecuencia en la visita que V.I. me tiene encargado enfermos cuyas afecciones trasladadas al papel por medio de la fotografía [...] podrían ser de sumo provecho para la enseñanza de la sifilografía y hasta seguramente de útil espejo para la juventud incauta, que, arrastrada por el torrente de ciertas pasiones, la ve precipitarse al repugnante vicio de la prostitución". Joan Soler i Buscallà (15 de julio de 1874). Citado por José Manuel TorREs, „Fotografía, delincuentes, enfermos y prostitutas en Barcelona (1867-1936)", Jornadas "La imatge i la recerca bistòrica [Girona, 12-14 noviembre de 1992]. 
importantes, tal como se reflejó en diversas publicaciones de las primeras décadas de nuestro siglo, por ejemplo las de Telesforo de Aranzadi, donde las fotografías de campesinos vascos eran utilizadas para confirmar las aseveraciones sobre el origen somático del pueblo vasco ${ }^{40}$. De la misma manera, el auge de un cierto panracialismo en los primeros años del siglo xx hizo que este tipo de imágenes tuviese una cierta aceptación, siendo utilizado en los discursos nacionalistas; un claro ejemplo lo ofrece Eugeni D'Ors, quien recurrió a la fotografía para demostrar los orígenes mediterráneos y clásicos de la cultura y de la población catalana.

Analíticamente, se puede decir que este tipo de fotografías (especialmente las de fines antropométricos) siguieron las directrices que se

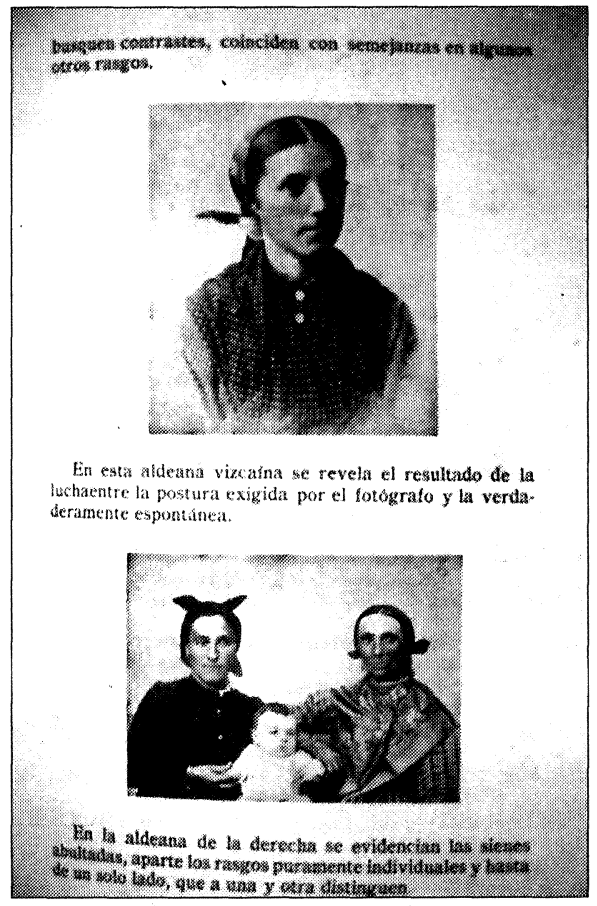

FIG. 7.-Telesforo de Aranzadi, De Antropología de España, 1915. "Aldeanas vascas". fijaron a lo largo del siglo XIX para esta clase de imágenes, directrices que pasaban, fundamentalmente, por el aislamiento de los sujetos de su contexto, situándolos sobre fondos neutros, desnudos o semidesnudos; de esta manera, el sujeto se convertía en un verdadero objeto de análisis, alejado de cualquier "variable" que pudiese alterar la preeminencia de lo orgánico por encima de lo cultural.

3. La fotografía judicial y policial.-Esta clase de fotografías tienen su origen en los cambios socio-culturales que la sociedad occidental sufrió a raíz de la Revolución Industrial; hay que hacer referencia, en especial, al hecho de que los individuos adquirieron un nuevo estatus: el de "entes autónomos" ${ }^{41}$. Recuérdese que, hasta este momento, las personas pertenecían a un estamento y su individualidad no importaba mucho, sobre todo la de los grupos subalternos. La fotografía, personalizando al sujeto,

40 Ver, por ejemplo, Telesforo DE ARANZADI, De Antropología de España (Barcelona: Estudio, 1915).

41 David LE Breton, Des visages (Paris: Métailié, 1992), pp. 41-42. 
su cuerpo y, sobre todo, su rostro, aportó su contribución a la celebración y a la proclamación de las personas como auténticos individuos autónomos y libres.

Con respecto a la fotografía judicial, hay que señalar, en primer lugar, que como consecuencia del desarrollo industrial decimonónico y, por lo tanto, del obrerismo y del aumento de la conflictividad social, diversas teorías sobre la criminalidad, tanto en lo que se refiere a los orígenes como a los sistemas de identificación, disfrutaron de una más que notable acogida. Así, los planteamientos de C. Lombroso ${ }^{42}$ sobre el criminal nato o los de Alphonse Bertillon sobre cómo identificar a los criminales tuvieron una importante influencia. En el caso que nos ocupa, Bertillon tuvo un papel esencial, ya que, desde su puesto de trabajo en la Prefectura de Policía de París, organizó todo un sistema para identificar y documentar a los criminales; en dicho sistema, la fotografía tuvo un destacado papel. Así, en 1890 publicó La photographie judiciaire, donde se destacó la importancia de esta técnica para la identificación de los delincuentes. Los resultados de sus trabajos hicieron que muchos países europeos adoptasen sus métodos. De esta forma, la fotografía se consagró como herramienta básica de identificación junto a la medición de la cabeza, el análisis del color de los ojos, del pelo, de la forma de los labios o de las huellas dactilares.

El "bertillonaje" fue adoptado en España rápidamente y, ya en 1895, el Gobierno Civil de Barcelona, publicó una Cartilla antropométrica ${ }^{43}$. Asimismo, su influencia se dejó sentir en muchas instituciones relacionadas con la justicia. Así, la Escuela de Criminología de Madrid llegó a crear un museo donde se ufueron acumulando aparatos de antropometría y psicometría, fotografías etnográficas, una interesante colección de fotografías de anarquistas y delincuentes profesionales" ${ }^{44}$. La fotografía contribuyó poderosamente al estudio y análisis de los rasgos "típicos" de los criminales; por ejemplo, cuando se describió a la famosa Mujer del Saco, se dijo que:

42 Su influencia se puede apreciar en obras como, Lombroso $y$ los anarquistas (Barcelona, 1896) de Ricardo Mella o El anarquismo en España y el especial de Barcelona (1897) de Manuel Gil Maestre.

43 Al respecto, se indicó que: "La Antropometría, en relación con las investigaciones gubernativas y judiciales, tiene hoy grandísima importancia para el descubrimiento de los delincuentes. Es esta ciencia un auxiliar de la justicia de decisivo valimiento, [...] en la ficha antropométrica, documento de indiscutible valor por hallarse en él condensados los rasgos que caracterizan la persona, tan invariables que aun en épocas remotas han de servir para su identificación". Gobierno Civil de Barcelona, Cartilla Antropométrica (Barcelona, 1895), pp. 11-12.

4 José RICO DE ESTASEN, "Los cráneos del Museo de la desaparecida Escuela de Criminologían, Revista de Estudios Penitenciarios, 1 (1945), p. 72. 
La mandíbula inferior es deforme para el ayuntamiento con la superior, y ofrece, asimismo, una notoria desproporción con el resto de los huesos de la cara [...] del estudio antropológico del mencionado cráneo [...] se deduce que la "Mujer del Saco" debió ser hembra sanguinaria y cruel, de sentimientos sádicos ${ }^{45}$.

Las indicaciones de Bertillon sobre cómo se debía fotografiar a las personas (de frente, de perfil...) para su rápida identificación se extendieron rápidamente, mas, hasta la fecha, la riqueza documental, fotográficamente hablando, que las cárceles u otras instituciones relacionadas con la justicia tienen, no ha sido estudiada con la debida atención.

4. La fotografía documental.-Desde los inicios de la fotografía en España hubo un número considerable de autores que, además de buscar aspectos estéticos, tuvieron un especial interés en dejar constancia gráfica de múltiples aspectos de la vida de los españoles. Así, desde las fotografías de Clifford sobre las labores de construcción del Canal de Isabel II, pasando por las de Spreafico sobre la construcción y el mundo del ferrocarril, las de Alcañiz Frías sobre las minas de La Carolina, hasta las de numerosas agrupaciones fotográficas de aficionados (por ejemplo, el Centre Excursionista de Catalunya) o, incluso, algunos profesionales a través del foto-reportaje, como Josep Rubaudonadeu en Girona, nos encontramos con que muchos de estos trabajos ofrecen, tal como se ha escrito en referencia a Clifford, "el rostro industrial, tecnológico y hasta sociológico de la España de su tiempo" ${ }^{46}$.

\section{LA FOTOGRAFÍA AL SERVICIO DE LA INVESTIGACIÓN ETNOLÓGICA: EL ARCHIVO DE ETNOGRAFÍA Y FOLKLORE DE CATALUÑa (1915-1930)}

En el anterior apartado he intentado presentar algunos de los ámbitos o clases de fotografía cercanos o propiamente antropológicos. A pesar de ello, hay que señalar que la mayoría, excepción hecha de la fotografía antropobiológica, no fueron el resultado de un interés primordial por documentar o registrar la cultura. A pesar del indudable valor de su testimonio para comprender un tiempo y unas expresiones culturales determinadas, los diferentes tipos de fotografía señalados se interesaron por las formas de vida pero como elemento accesorio, no como eje central de

45 Ibid., p. 74.

46 Publio LóPEZ MONDÉJAR, Las fuentes de la memoria. I. Fotografía y sociedad en la España del siglo XIX (Barcelona: Lunwerg, 1982), p. 35. De este mismo autor, ver su reciente obra, Historia de la fotografía en España (Barcelona: Lunwerg, 1997). 
un discurso o de una actuación decididas, donde la fotografía jugase un papel de primer orden en el desarrollo del trabajo etnológico.

Con todo, debo referirme aquí a una actuación que, históricamente, representa uno, por no decir el primero, de los más importantes avatares que se han dado en España en cuanto a la utilización, de manera sistemática, de la fotografía por parte de la antropología. Me estoy refiriendo al Archivo de Etnografía y Folklore de Cataluña (AEFC), entidad que, a pesar de no ser la primera en plantear la necesidad de utilizar el registro gráfico en la investigación etnográfica (al respecto, recuérdense las aseveraciones de Antonio Machado y Álvarez ${ }^{47}$ ), sí fue la pionera en España en su uso continuado, dentro de un amplio plan de investigación etnográfica, hasta el punto de que el AEFC estableció un decálogo de cómo se debía usar la cámara fotográfica en la recolección de datos ${ }^{48}$. Aquí solamente me centro en los aspectos visuales; remito a otras publicaciones para conocer o profundizar en otros aspectos de la entidad ${ }^{49}$.

La innovación que supusieron las labores del AEFC en el mundo antropológico hispano se reflejó en su decidida apuesta por el uso de la fotografía como auténtica herramienta para la investigación. Así, el Manual per a Recerques d'Etnografia de Catalunya (Barcelona, AEFC, 1922), ya dedicó un capítulo a este tema, el titulado Secció Gràfica, donde se puede leer la declaración más importante del AEFC con respecto a la utilización de la fotografía en los trabajos etnográficos — de hecho, se puede considerar que es uno de los textos más ajustados sobre la relación entre las dos disciplinas de la historia de la antropología española-:

És de la major importància i utilitat completar tota investigació etnogràfica amb fotografies que serveixin d'il.lustració i aclariment. Tot sovint, una fotografia explica més que llargues descripcions. A l'emprendre la investigació de la cultura popular d'una localitat o comarca determinada, és preferible no refiar-se de les fotografies ja fetes, i que el recercador en faci d'altres en totes aquelles ocasions que ho requereixin les necessitats de la recerca. Un aparell fotogràfic facil de portar i manejar és imprescindible en l'equip de tot investigador en ses excursions etno-

47 Así, Machado y Álvarez llegó a decir que: "En la recolección de materias, todos y cada uno de los centros del Folk-lore [...] tendrán como principal objetivo [...] utilizando, cuando el estado de sus recursos lo consienta [...] dibujo, taquigrafía, fotografía y demás medios adecuados para obtener fidelidad de reproducción". Citado por M. de los Santos García Felguera, "Sevilla: en blanco y negro", VV. AA., Fotógrafos en la Sevilla del siglo XIX (Sevilla: Fundación Focus, 1994), p. 184.

48 Ver Luis Calvo, Josep Mañà y Juan NaRANJo, Temps d'abir. Arxiu d'Etnografia i Folklore de Catalunya 1915-1930 (Barcelona: Fundación ala Caixa", 1994).

49 Luis Calvo, El "Arxiu d'Etnografia i Folkore de Catalunya" y la antropología catalana (Barcelona: CSIC, 1991). 
gràfiques [...] Les fotografies etnogràfiques han d'ésser una còpia exacta de la realitat, de manera que no s'intentarà mai fer grups artístics o preparar l'escena [...] tota fotografia ha d'anar acompanyada d'una descripció en què s'exposin tots els detalls d'interès que facin referència a l'assumpte representat ${ }^{50}$.

Esta concepción estuvo, asimismo, bien explicitada en la definición del trabajo que el AEFC tenía que realizar: "El Folklore es una ciencia compleja, no un arte. Por eso no precisa que el folklorista sea artista o literato, sino psicólogo y naturalista; he aquí por qué más bien necesita del fonógrafo y del Kodak que del cincel y de retoricismos" ${ }^{51}$.

Es bien conocido que para que se dé cualquier transformación científica, es necesaria la articulación de nuevos conceptos teóricos así como de nuevos instrumentos metodológicos. Si, en el primer caso, el AEFC lo formalizó a través del concepto de psicoetnografía ${ }^{52}$, en el segundo, además del recurso sistemático a la encuesta mediante cuestionarios u otros elementos, lo hizo creando un discurso y una actuación propias, gracias a la utilización del registro gráfico, lo que posibilitó documentar mucho mejor su objeto de estudio. Este aspecto permite aquí recuperar el concepto de "emicn: la fotografía se constituyó en un elemento que tradujo en imágenes la visión que tenía el AEFC de la realidad y de lo que era el trabajo etnográfico, lo que, con el paso del tiempo, permite comprender y penetrar mejor en un determinado momento de la historia de nuestra etnografía así como en las conceptualizaciones de una época.

Reflejo de ello es que, a pesar de que la fotografía ayudó a los miembros del AEFC a implicarse de manera más directa ${ }^{53}$ en la vida de las comunidades estudiadas (pescadores, campesinos, etc.), en la entidad se reflejaron creencias de su época - por ejemplo, la concepción sobre las formas de vida ${ }^{54}-\mathrm{o}$, incluso, persistieron algunas ideas heredadas del

50 Arxiu d'Etnografia i Folklore de Catalunya, Manual per a Recerques d'Etnografia de Catalunya (Barcelona: Universitat de Barcelona, 1922), pp. 33-34.

51 Comunicación de Jaume Oliver Castañer a Tomàs Carreras i Artau, Barcelona, 24-12-1916. Archivo AEFC (Institución Milá y Fontanals. CSIC. Barcelona).

52 Ver Luis Calvo Calvo, "Tomàs Carreras i Artau y la Psicoetnografía. El primer antecedente de la Etnopsicología en Españan, Anuario de Historia de la Antropología Española, 1 (1992), pp. 27-37.

53 En este sentido, casi se podría hablar de la "cámara participante", definición que Jean Rouch aplicó a sus trabajos sobre Robert Flaherty. Jean Rouch, "Le film ethnographique», Jean Poirer (ed.), Ethnologie Générale (Paris: Gallimard, 1968), pp. 447-455.

54 La Guia de l'Arxiu Gráfic del AEFC explicita la configuración etnológica que la entidad tenía; los apartados en que estaba dividida eran: "MENTALITAT. Tipus. Tipus tradicionals. Tipus ambulants. Gestos tradicionals. Actituds. Habilitats personals. CUL- 


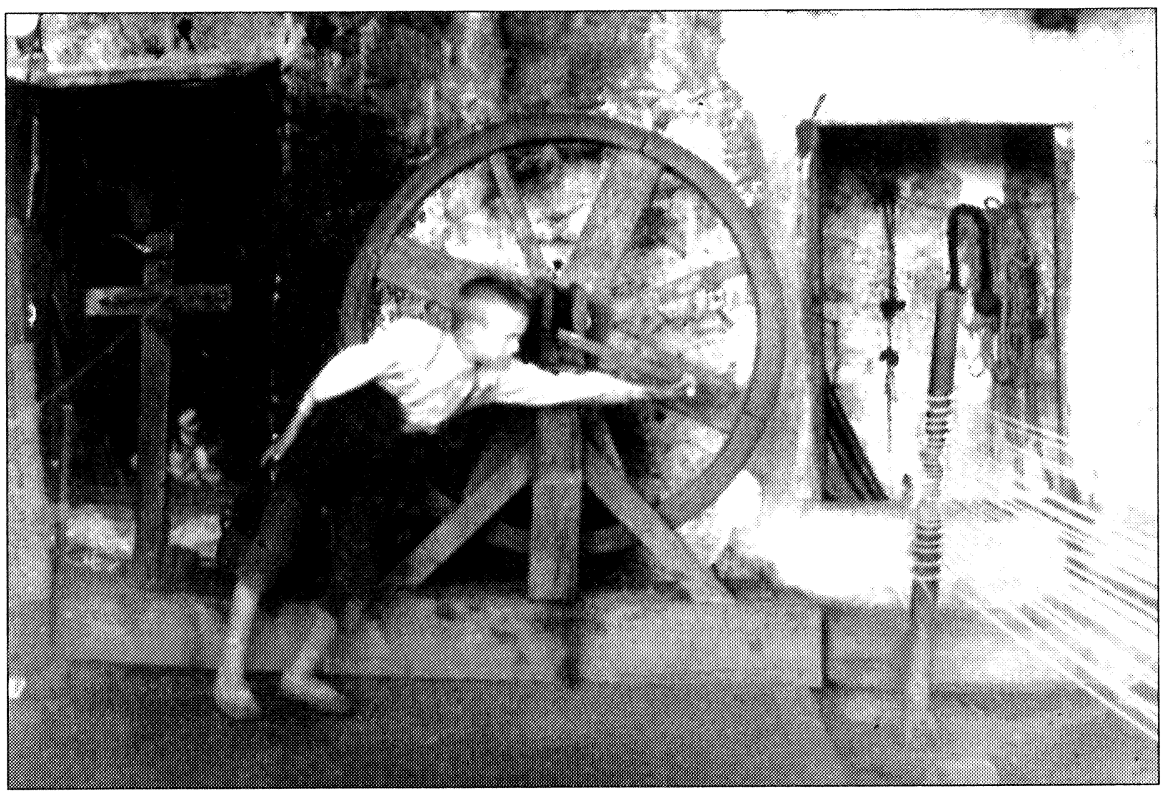

FIG. 8.-Arxiu d'Etnografia i Folklore de Catalunya.

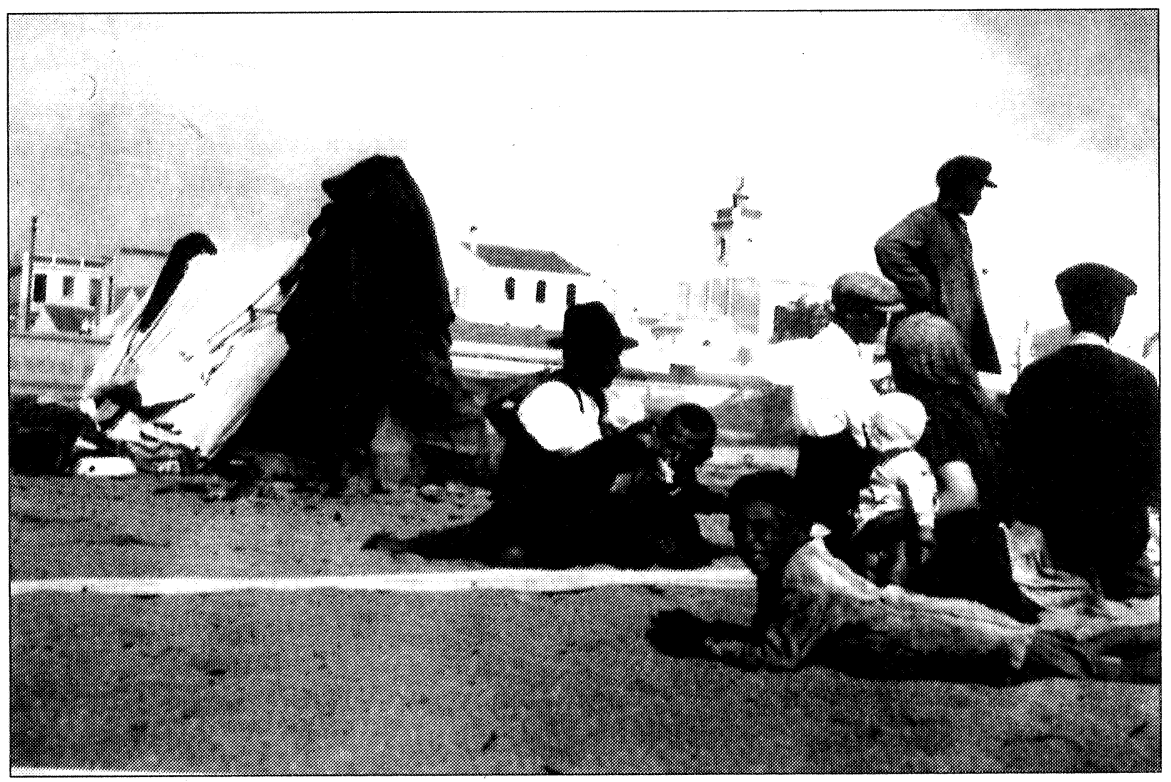

FIG. 9.-Arxiu d'Etnografia i Folklore de Catalunya. 
siglo $\mathrm{XIX}^{55}$-como, las referidas a la psicología de los pueblos ${ }^{56}$ o la antropología física decimonónica ${ }^{57}$.

Si se estudia con detenimiento el uso de la imagen por parte del AEFC, se puede observar que, en la concepción renovadora de la entidad, aquélla se convirtió en un elemento articulador del trabajo a realizar, convirtiéndose en un auténtico motor de renovación de la labor etnográfica, tal como

TURA. Agençament corporal. La infància. Indumentària $i$ objectes infantils. Jocs $i$ joguines d'infants. L'escola. L'babitació i la vida domèstica. L'exterior: les construccions. Cabanes, barraques, etc. Masies. Masies fortificades. Construccions accessories (porxos, pous, etc.) Rellotges de sol. Detalls externs de la casa. L'interior: el mobiliari. L'alimentació: el porró. Feines domèstiques. L'art popular: Fonts i llocs d'esbarjo. Treballs d'escultura o decoració. Instruments musicals populars. Representacions dramàtiques populars. Religiositat popular. Santuaris. Ex-votos. Processons: Festes de l'Any. Capelletes de carrer. Pregàries. Màgia. Llocs llegendaris. Medicina popular. Vida social i jurídica. Poblats (viles, pobles, veinats, etc.). Passeres i ponts. Hostals. Reclams i plàstica popular. Gremis, confraries $i$ germandats. Batlles, regidors, jutges, agutzils, pregoners. Fires $i$ mercats. Les jornades de la vida. El naixement $i$ el bateig. El matrimoni. La mort. Ocupacions i tecnologia popular. Caça. Pesca: Pesca fluvial. Pesca marítima. Vida dels pescadors del mar. Subhasta del peix. Navegació. Pastoreig. Agricultura. Preparació del camp. La sembra. Llaurar: L'arada. La sega. Les garberes. La batuda. El paller. El blatde-moro: Regadius. Altres feines del camp. L'explotació del bosc. Molineria. Indústries del llí $i$ del cànem. Ceràmica. Altres oficis. Transports. Festes $i$ diades. Festes de l'any: Nadal. El Ram. Corpus. Setmana Santa. Pasqua Florida (Caramelles). Pasqua Granada (Festa de les Espigues). Sant Roc. Festa de Maig. Sant Isidre. Sant Jordi. Sant Antoni Abat. Festes de Carrer. Festa del Pi de Sta. Coloma: Centelles. Aplecs. Santuaris. Jocs, deports $i$ danses. Jocs $i$ deports de gent gran. Danses". Archivo AEFC (CSIC. Barcelona).

${ }_{55}$ Por ejemplo, el concepto de "tradicional" y los valores que con él estaban asociados; así, cuando Carreras i Artau hablaba de las restauraciones en masías decía que: "Masia de Can Vinyas. És una masia restaurada i en part modificada, però tot fet amb molt d'encert i prenent l'aire tradicional.. Luis CALvo, Catàleg de materials gràfics de l'A.E.F.C. (Barcelona: CSIC y Centre de Promoció de la Cultura Popular i Tradicional Catalana, 1994), ficha número 0094.

56 En concreto, la división de personas en base a categorías mentales: "home folklòric" (campesinos, pastores, pescadores, vendedores ambulantes, etc.), "home salvatge" (pueblos primitivos), "home prehistòric", etc.

57 El AEFC tenía por norma, en cualquier descripción, señalar los rasgos físicos más relevantes, teniendo como patrón la siguiente ficha antropológica: "Fitxa antropològica-fotogràfica. 1. Color de la pell. a) roig. b) ros. c) castanya. d) obscur o negre. 2. Color dels ulls. a) clars (blaus, verds, pissarra, avellana). b) mitjans (d'intensitat de color). c) obscurs o negres. 2 bis. Color de la pell. a. blanca. b. morena. 3. Edat. 4. Estatura. Alta. Mitja. Baixa. 5. Origen dels seus pares i avantpassats (si eren fills de la localitat o hi han residit mots anys, o bé d'on procedien. Llur professió o ocupació). Noms i motius. Si sap o no llegir i escriuren. Este interés por el aspecto físico respondía a su preocupación por indagar en los orígenes étnico-raciales de la población, es decir, por la etnogénesis. 
se puede observar, por ejemplo, en la narración visual ${ }^{58}$ de secuencias de acciones (obtención de carbón vegetal, preparación del campo para la siembra, trabajos de la siega, procesiones, etc.) vertebradas a partir de grandes series temáticas ${ }^{59}$. Secuencias que permiten adivinar los múltiples aspectos de la realidad gestual, ritual, simbólica, comportamental, así como los vínculos - cadenas o ligámenes ${ }^{60}$ - o contactos concretos y efectivos, encadenamientos que se dan entre la persona y la herramienta o entre el hombre y el animal. De esta forma, las llamadas "excursiones etnográficas" ${ }^{61}$ fueron la base del amplio trabajo etnográfico de carácter fotográfico que el AEFC llevó a cabo, tal como quedó reflejado en los cuadernos del fundador del AEFC, Tomàs Carreras i Artau, quien anotaba en ellos los detalles más significativos de cada fotografía que realizaba. Así, texto e imagen se conviertieron en un instrumento inmejorable para aproximarse al conocimiento de, por ejemplo, el trabajo de hombres, mujeres ${ }^{62}$ y niños ${ }^{63}$, de la precariedad del medio, de los ritmos vitales ligados a la naturaleza, de la convivencia de útiles ancestrales (por ejemplo, mayales) con la creciente mecanización del campo o de las relaciones entre grupos étnicos ${ }^{64}$.

58 Ver la siguiente descripción de Carreras i Artau sobre la labor fotográfica en una jornada completa de trabajo de campo [refiriéndose a unos trabajos relacionados con la siegal: "Les operacions fotografiades a que's refereixen les vistes següents són: segar (n'hi moltes i en diverses posicions). Fer la garba i deixar-la al camp. El camp en bona part segat, amb les garbes exteses. Once hores, o sigui 'beure' (vi amb una galeta), que jo he fet també amb els segadors. Esmolar el volant. La colla de Segadors es fa amb gent de la localitat. Posem ara els números de les fotografies tirades, a les quals posarem després el tema concret, reconstituint el procés de la sega, tal com l'hem presenciat". Luis Calvo Calvo, Catàleg de materials gràfics de l'A.E.F.C., ficha 0501.

59 Con el fin de evaluar mejor la innovación que supuso la realización de $s e-$ cuencias, hay que tener en cuenta que esta idea se extendió en el mundo del film etnográfico a partir de 1968 con los trabajos de Timothy Asch y Napoleón Chagnon. Emilie DE BRIGARD, "Historique du film ethnographique", Claudine de France (dir.), Pour une Anthropologie Visuelle (Paris: Mouton, 1979), p. 43.

60 Ver Claudine DE FRANCE, Cinéma et Anthropologie (Paris: Maison des Sciences de l'Homme, 1989), pp. 169-210.

${ }_{61}$ En los mencionados Quaderns de Fotografies de Carreras i Artau se pueden leer los "instrumentos" básicos del etnógrafo para las salidas de estudio: "Llista d'excursionista: Horari dels trens, autobusos, etc. Diner (en primer lloc). Tabac. Maquina. Tripode. 2 lentes. Pel.lícoles. 2 llibrets (Aquesta cartera i el Manual Kodak). Manual Arxiu. Ganivet. Esmorzar. Cinta mètrica. Capsa del Magnesi. Vaset. Encenedor. Pito".

62 Luis Calvo, Catàleg de materials gràfics de l'A.E.F.C., ficha 1803.

63 Ibid., ficha 0752.

oi Ibid., ficha 1775 . 
Esta implicación directa remite a toda una serie de aspectos que hicieron que la labor etnográfica de la entidad fuese novedosa; entre ellos hay que destacar:

1. La contextualización de las imágenes. Frente a la costumbre del momento que tendía a aislar a los sujetos de su contexto habitual -aspecto relacionado íntimamente con el interés por captar los rasgos psicológicos e identitarios de los individuos y pueblos ${ }^{65}$ - el AEFC realizó buena parte de su trabajo fotografiando el hombre en su medio, lo que acrecienta el valor de sus imágenes.

2. La narración visual de secuencias de acciones, que permiten observar diferentes aspectos de las formas de vida.

3. El encadenamiento de personajes y situaciones que se dan entre el hombre y el instrumento, entre los hombres cuando trabajan o en sus relaciones con el mundo vegetal y animal.

4. Estos aspectos nos remiten de hecho, y tal como escribió E. Edwards, a una "etnografía de la experiencia", ya que el AEFC puso un especial acento en las expresiones y las experiencias de los "sin historia".

5. Las imágenes alcanzan una expectativa tal que se puede hablar de una verdadera "densidad de la experiencia". Así, si fijamos nuestra mirada en el mundo de la pesca, las imágenes revelan los rituales y los trabajos de los hombres y de las gentes del mar. Si algunas imágenes hechas por Carreras i Artau no fueron para ser leídas, éstas sí, ya que percibimos cómo el etnógrafo se inserta en la situación concreta, se mete en la arena y obtiene planos que difícilmente se podrían lograr de otra manera. Así, las fotografías de la fiesta de Sa-morra morra en la playa de Santa Cristina revelan las relaciones sociales: las mujeres y los niños en la playa; los sacerdotes bendiciendo toda la ceremonia; la presencia del poder militar (la Guardia Civil) y otros muchos aspectos ${ }^{66}$.

Asimismo, hay que destacar la captación precisa del momento, del instante ("el instante fecundo"); de esta manera, por ejemplo, Carreras i Artau captó en su ciudad natal, Girona, los juegos de los niños, totalmente ensimismados, aunque siempre hay alguno que percibe la actuación del etnógrafo, con lo que la imagen gana en intensidad expresiva ${ }^{67}$.

65 En este sentido, hay que recordar que Margaret Mead, hacia 1925, utilizaba la fotografía para la captación y descripción de reacciones psicológicas de los jóvenes de Samoa, recurso que empezó a usarse en los estudios psicológicos hacia 1909. Ver Emilie DE BRIGARD, "Historique du film ethnographique", p. 39.

w6 Elizabeth EDwards, "Exhibition reviews. Temps d'ahir", Journal of Museum Ethnography, 7 (1995), p. 142.

67 Ibid., p. 141. 


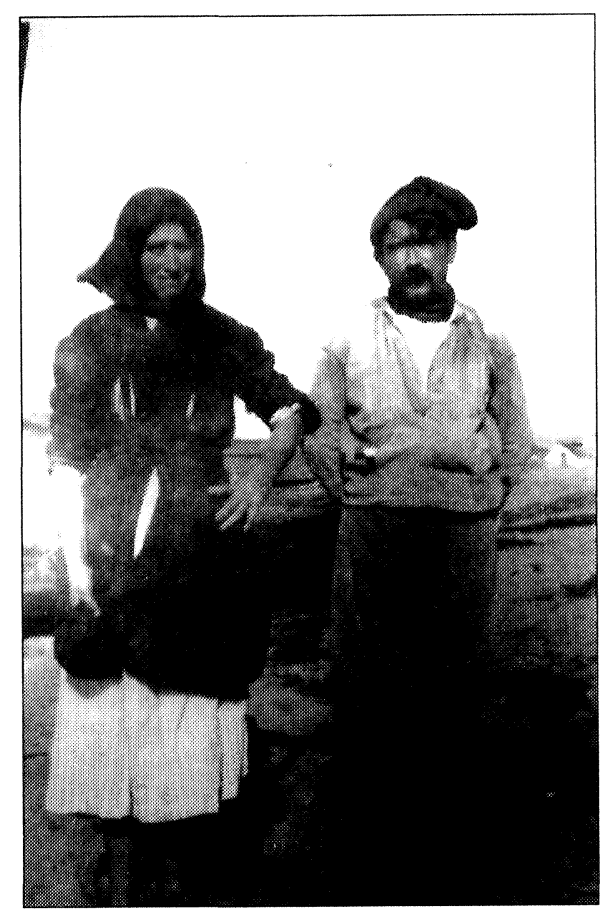

FIG. 10.-Arxiu d'Etnografia i Folklore de Catalunya
Según estas consideraciones, se puede decir que la fotografía jugó un papel de primer orden en el AEFC en su objetivo de documentar las formas de vida del momento: de hecho, se puede afirmar que el recurso a la fotografía fue un proceso integral de la investigación de campo, no meramente un producto; así, se puede hablar de un verdadero tour de force de la documentación y del método ${ }^{68}$. El trabajo del AEFC permite situar el discurso etnográfico y el fotográfico más como posiciones complementarias que como polos opuestos entre "estética" y "objetividad" ${ }^{69}$ En definitiva, la labor del AEFC presentó, por primera vez en España, las posibilidades que ofrecían las nuevas técnicas de registro, en concreto, la fotografía.

El artículo presenta diversas variables que han incidido, de manera notable, en la relación entre antropología y fotografía entre 1839 y 1936 . Asimismo, se establece una inicial división de las principales clases de fotografía antropológica. Finalmente, se analiza una de las primeras tentativas de utilización de la fotografía por parte de la etnografía en España: el Archivo de Etnografía y Folklore de Cataluña.

The author introduces a number of variables that remarkably bear on the relationship between photography and anthropology from 1839 to 1936 . He also establishes a preliminary system of classification of anthropological photographs. Finally, he analyzes one of the first attempts made in Spain of the use of photography in ethnography: that of the Archivo de Etnografia y Folklore de Cataluña.

\footnotetext{
68 Ibid., p. 140.

69 Ibid., p. 142.
} 